
Numerical and experimental study on unsteady pressure field around cubes

\author{
村上 周三*1, 日比 一喜*2, 持田 灯*3
} Shuzo MURAKAMI, Kazuki HIBI, Akashi MOCHIDA

\title{
SUMMARY
}

In this paper, fluctuating pressure fields around cubes are examined using both numerical, simulations and wind tunnel tests. 3D, time-dependent numerical simulations based on Large Eddy Simulation were carried out in order to clarify the relation between the structures of unsteady flowfields around cubes and the fluctuating surface pressure fields. Accuracy of the numerical simulation was assessed by comparing the numerical results with the results of wind tunnel tests using the Multi-Channel Simultaneous Pressure Measuring System. It was confirmed that the shapes of the numerically predicted spectra of fluctuating drag and side forces correspond very well to those of experimental data. Furthermore the numerical simulation can reproduce the characteristic pattern of the surface pressure fluctuations rather well.

It was observed from the numerical results that the sharp peak appears in the wave pattern of the side force fluctuation when a large scale vortex occurs in the separated flow region near the side wall.

1.はじめに

本研究では多点圧力同時測定システムを用いて
立方体ブロックにより構成される均等な街区モデ ル中の建物表面の非定常な圧力分布を測定した。

*1 東京大学生産技術研究所, 教授, 工博

Institute of Industrial Science, Univ. of Tokyo, Prof., DR.

* 2 清水建設技術研究所

Institute of Technology, SHIMIZU Corp.

*3 東京大学生産技術研究所, 助手, 工博

Institute of Industrial Science, Univ, of Tokyo, DR.

（本稿受理：平成元年12月15日） 
一方LESに基づく数値解析から流れ場の圧力及び 建物表面風圧の分布を求めた。次に両者を関連づ けて考察し，建物近傍の圧力に関わる乱流現象を 解析することを試みた文(1)（2)。

これらの建物表面や空間の非定常な圧力分布は 構造物の振動や建築物の換気に関わる現象を解明 するための基礎資料として重要である。これらの 問題に関して過去さまざまな研究がなされてきた が充分に定量的な考察がなされるには至っていな かった。

本報では風洞実験と数值解析の比較検討により， 建物前後差圧及び建物側壁面差圧の非定常な時間 変動を考察し，この中に見いだされる特徵的なパ ターンに着目した。又，この時点のデータを抽出 し，スペクトル解析等の統計処理だけでは把握す ることが困難な流れ場の圧力や流速の空間分布と 壁面風圧分布のパターンとの関係を詳しく調べた。 またこれらの現象に関わって生じる建物角部から 発生する剩離領域の中の渦の非定常。時間変化に ついて検討した。

\section{2. 数值解析の概要}

\section{1 計算対象}

Fig. 1に示す隣棟間隔 $3 \mathrm{H}_{b}$ の街区を対象としてい る。この中の 1 つのユニットを対象にして解析し た。この $3 \mathrm{H}_{b}$ 街区は，一般的にストリートキャニ オ乡と言われている隣棟間隔 $1 \mathrm{H}_{b}$ 程度の街区と, 䇟棟間隔が非常に大きい独立に近い建物の中間的 な性質を有し，風工学的にも興味深い対象と考え られる文(3)。

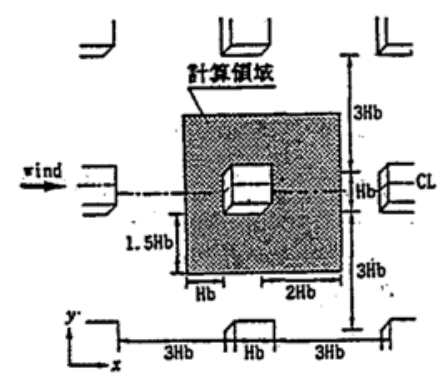

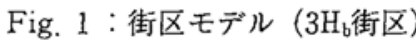

\section{2 基礎方程式}

Large Eddy Simulation (以降LES) を用いて3 次元乱流の数值解析を行った。以下にLESの基礎 式を示す。

$$
\frac{\partial \bar{u}_{i}}{\partial x_{i}}=0
$$

$\frac{\partial \bar{u}_{i}}{\partial t}+\frac{\partial \bar{u}_{i} \bar{u}_{j}}{\partial x_{j}}=-\frac{\partial}{\partial x_{i}}\left(\frac{\bar{P}_{j}}{\rho}+\frac{2}{3} k^{*}\right)+\frac{\partial}{\partial x_{j}}\left(\nu+\nu_{S G S}\right) \bar{e}_{i j}$

但し，

$$
\begin{gathered}
\nu_{S G S}=(C, \Delta)^{2} \cdot\left(\frac{\bar{e}_{i j}{ }^{2}}{2}\right)^{1 / 2}, \quad C s=0.1 \\
e_{i j}=\frac{\partial u_{i}}{\partial x_{j}}+\frac{\partial u_{j}}{\partial x_{i}}, \quad i, j=1,2,3
\end{gathered}
$$

なお，フィルタリングにはトップハット：フィル ターを用いている。詳細は文献(4).(5),(6)を参照 されたい。

\section{3・メッシ之分割}

Fig. 2に示す52 (x) $\times 55(y) \times 45(z)=128,700$ の差 分格子を用いている。屋根面, 側壁面の風上側角 部周辺には,メッシュ幅1/40Hbの細かい格子を， 建物壁面か50.3H。離れた距離まで配置している。

\section{4 差分スキーム}

時間にはAdams-Bashiforhスキーム，空間には2 次精度の中心差分を用いている。まだ、メッシュ 系はスタガードメッシュを用いている。

\section{5 境界条件}

流れ方向 $(\mathrm{x})$ ，流れと直交方向（y) に周期境界条 件を用いている。この周期境界条件を用いること により計算領域中に建物を 1 つのみ定義するだけ で，近似的に複数の連続した街区と見なすことが 可能である。また地上面，建物壁面に指数 $1 / 2$ の power lawを用いた境界条件文(6)を使用している。 上空面はfree slipではなく, 指数 $1 / 4$ の power law で近似される鉛直速度分布が連続しているものと した境界条件を与えている。またここでは流れ 


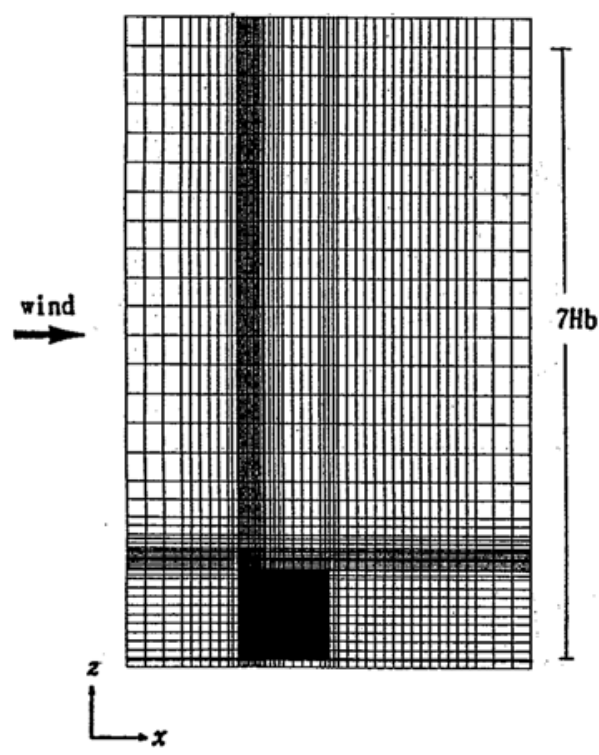

(1) 铅直断面 $(52(x) \times 45(z))$

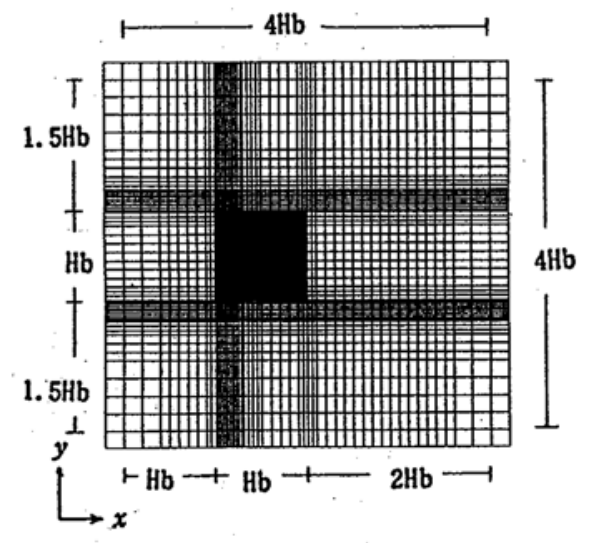

(2) 水平断面 $(52(x) \times 55(y))$

Fig. 2 :メッシュ図

方向に圧力損失 $\Delta \mathrm{P} / \mathrm{p}<\overline{\mathrm{u}_{\mathrm{b}}}>^{2}=2.2 \times 10^{-5}$ を与 えている。

\section{3. 風洞実験の概要}

1 辺 $10 \mathrm{~cm}$ の立方体模型を $30 \mathrm{~cm}$ 間隔で横6列, 流れ方 向に47列配置し, 風上側より 44 列目に圧力測定用 の模型を設置した。圧力測定点は模型各面に $8 \times 8$ $=64$ 点, 模型全面で320点である。非定常圧力測定 は1. $5 \mathrm{msec} の$ 時間間隔で行ない, 全測定点同時計測 を行っている。なお計測システムの詳細は文献(7). (8) , (9) , (10)を参照されたい。ここで模型高さH。 $(10 \mathrm{~cm})$, 棟高風速 $<\mathrm{u}_{b}>\left(\right.$ 建物風上 $1 \mathrm{H}_{\mathrm{b}}$ の位置で $11.2 \mathrm{~m} / \mathrm{s})$ によるレイノルズ数は $8 \times 10^{4}$ となってい る。無次元化は建物高さ $\left(H_{b}\right)$ と棟高風速 $\left(<u_{b}>\right)$ を 用いて行っている。

\section{4. 建物前後差圧, 側面差圧の波形, スペクトル}

筆者らの既往の研究 ${ }^{(4)},(5),(6)$ では主として風 速変動の性状について, 数值解析と風洞実験によ り調べ，両者がよく対応することを既に確認した。
Fig. 3(1)に風洞実験の建物前後差压 $\Delta \mathrm{P}_{\mathrm{D}}$ （風上 面一風下面) の変動波形，(2)に数值解析のそれを 示す。またFig, 4(1):に風洞実験の建物側面差圧 $\Delta \mathrm{P}_{\mathrm{L}}$ (ここでは左側壁面一右側壁面）の変動波形，(2) に数値解析のそれを示す。これらの波形を得るた めの計算量は膨大で, 計算ステップで約 30 万,VP100 クラスのスーパーコンピュータで約50１00時間を 要するため, 今回の計算は無次元時間 $\mathrm{t}^{*}=125$ で止 めた。

ここで風洞実験におけるサンプリングは $1.5 \mathrm{msec}$ の時間間隔で2048個の波形データーを収録してい る。また数值解析におけるサンプリングは計算時 間間隔 $0.0003\left(<\overline{u_{b}}\right\rangle$ と $H_{b} に よ る$ 無次元時間)に対 して, 100ステップ間隔で波形データーを収録して おり, フィルタリングは行っていない。従って風 洞実験の無次元化されたサンプリング間隔 $\Delta \mathrm{t}^{*}$ は $0.0015(\mathrm{sec}) \times 11.2\left(<\mathrm{u}_{\mathrm{b}}>, \mathrm{m} / \mathrm{s}\right) \cdot / 0.1\left(\mathrm{H}_{\mathrm{b}}, \mathrm{m}\right)=0.16$ となる。一方,数值解析の無次元化されたサンプリン グ間隔 $\Delta \mathrm{t}^{*}$ は $0.0003 \times 100=0.03$ となる。数值解析の 最大メッシュ幅 $0.2 及 ひ ゙$ 最小メッシュ幅 0.025 を棟 


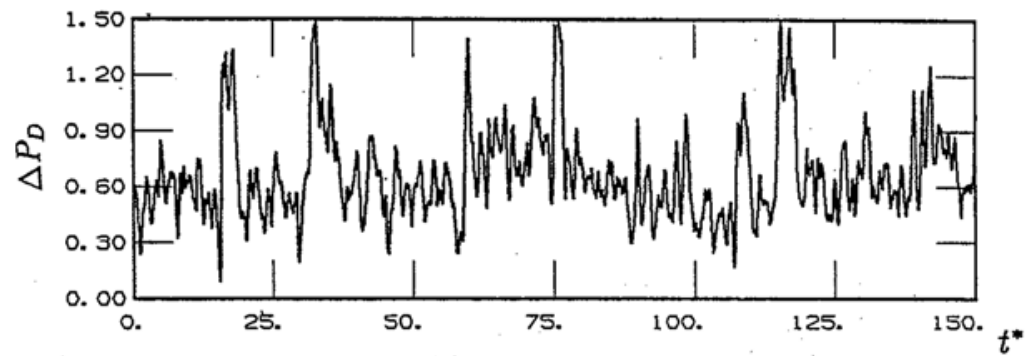

（1）風洞実験

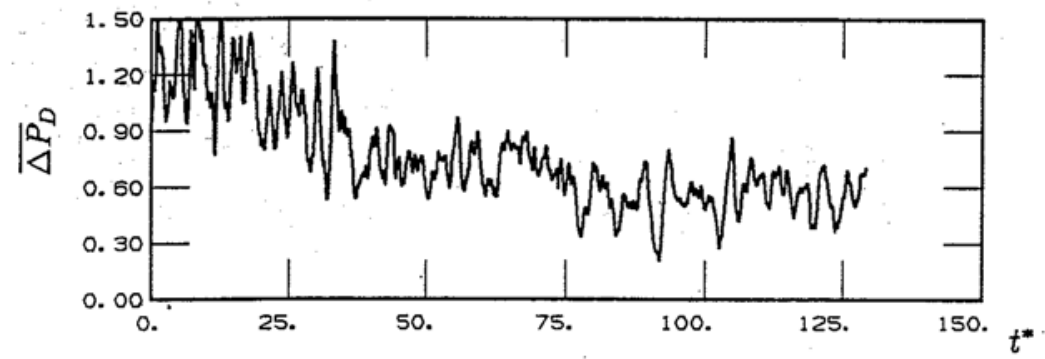

（2）数值解析

Fig. 3 : 建物前後差圧 $\Delta \mathrm{P}_{\mathrm{D}}$ の変動波形

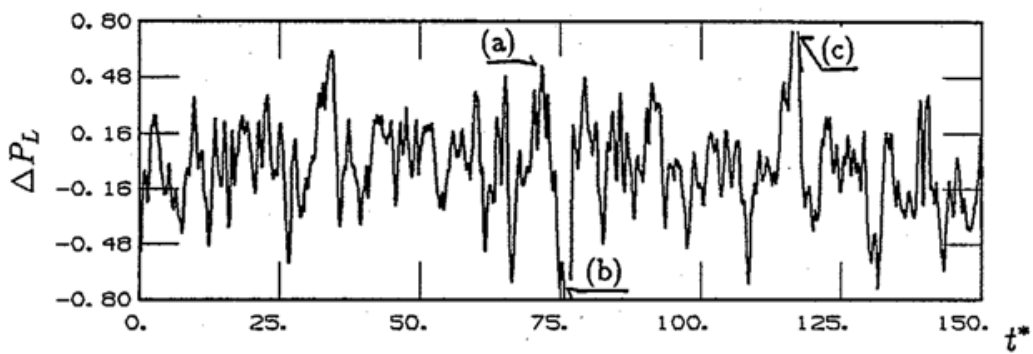

（1）風洞実験

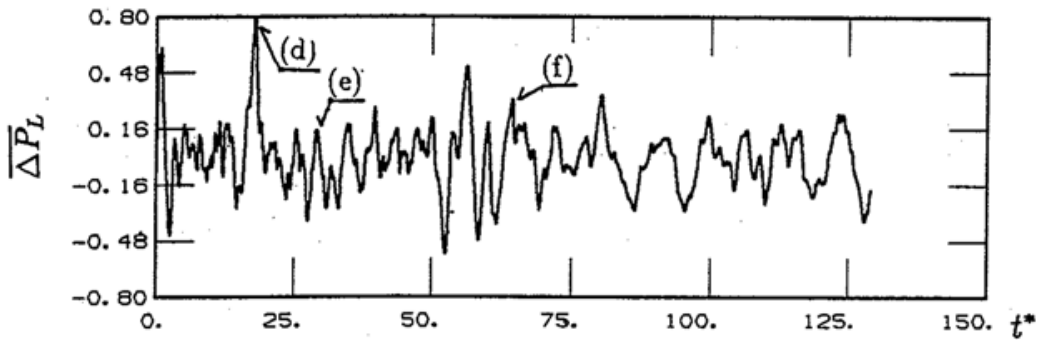

（2）数值解析

Fig. 4 : 建物側面差圧 $\Delta \mathrm{P}_{\mathrm{L}}$ の変動波形

高風速 $\left\langle\overline{u_{b}}>\fallingdotseq 0.6\right.$ 流体が通過する無次元時間は ると考えられるが, むろんもっと粗いサンプリング それぞれ0.3及び0.04となる。従って最小メッシュ＼cjkstart間隔を採用することも可能である。一方, 実験の 幅で決まる最も小スケールの変動を捉えるサンプサンプリングは, 中間的なメッシェスケールに対 リング時間間隔として, 0.03 前後の值は適当であ 応するものとなっている。 
風洞実験における建物前後差圧の波形 (Fig. 3

（1）をを見ると圧力差が他の時点に比べてかなり大 きくなる時点が間欠的に出現している。これらの 現象は建物側面差圧の波形 (Fig. 4(1)) にも見ら れる。側面差圧が大きくなる時点は前後差圧が大 きくなる時点に同期している。ただし前後差圧が 大きくなる全ての時点で側面差圧が大きくなって はいない。

風洞実験の側面差圧の波形（Fig. 4(1)）を見る と前後差圧のような長周期の変動は顕著ではない が, やや周期性を持った変動 (無次元時間5程度の 周期) が顕著に認められる。数值解析における測 面差圧の変動(Fig. 4(2)) にも風洞実験と同様の大 きなピーク值を持つ差圧変動が間欠的に現れてい る。また, 風洞実験と同様に, やや周期性をもっ た無次元時間 5 ,程度の周期の変動が見られる。

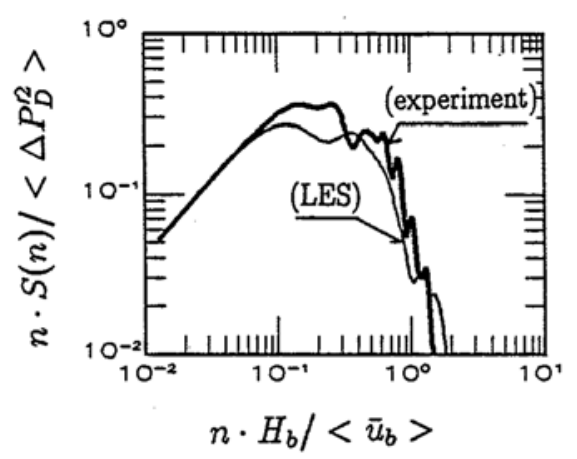

Fig. 5 : 建物前後差圧 $\Delta \mathrm{P}_{\mathrm{D}}$ 変動のスペクトル

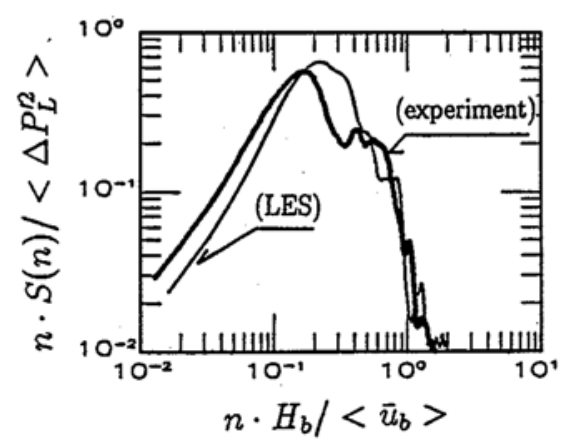

Fig. 6 : 建物側面差圧 $\Delta \mathrm{P}_{\mathrm{L}}$ 変動のスペクトル
Fig. 5に建物前後差圧の変動スペクトル, Fig. 6 に建物側面差圧の変動スペクトルを示す。側面差 圧の変動スペクトルは前後差圧の変動スペクトル に比ベて狭帯域であり，スペクトルピークもやや 高周波側に偏っており，この傾向は風洞実験と数 值解析でよく一致している。このように風洞実験 と数值解析の変動スペクトルの一致は概ね良い。

\section{5. 風洞実験における壁面の変動風圧係数分布の 解析}

Fig. 7(1)，(2)，(3)にFig. 4(1)の $\Delta \mathrm{P}_{\mathrm{L}}$ の変動波 形に示した $(a) \sim(c)$ の 3 時点における風洞実験の 建物表面の風圧係数 $\mathrm{C}_{\mathrm{p}}$ の瞬時分布を示す。Fig. 4 (1)の (c) 時点は他の時点に比べて正の差圧のピー ク值が大きくなっている時点で, Fig. 7(3)にその 時点における建物表面の風圧分布を示す。(b) 時 点は (c) 時点とは逆に, 負の差圧のピーク値の大 きな時点を抽出した。(a) 時点は (b) 時点に隣接し た正の差圧のピーク值を示す時点が抽出されてい る。負圧の值が-1.0を示す領域に着目して各時刻 を比較すると, (c) 時点と (a) 時点では全壁面で大変 よく似ており，特に風上側から見て右側の側壁面 で-1.0の負圧が大きな領域を占めていることが特 徴である。(b) 時点の圧力のパターンは (a) 時点と は反対の左側側壁面で-1.0の負圧が大きな領域を 占めている。

風上面の風圧分布は (a) と (c) が似ているが $(b)$ は異なっている。屋根面の風圧分布についても (a) と (c) は大変よく似ている。

\section{6. 数值解析による流れ場の圧力分布と建物表面 の压力分布の解析}

Fig. 8〜10に, Fig. 4(2)の建物側面差圧 $\Delta \mathrm{P}_{\mathrm{L}}$ の 変動波形に示した $(\mathrm{d}) \sim(\mathrm{f})$ の 3 時点における数値 解析の建物表面と流れ場の圧力の瞬時分布を示す。 またFig. 11に (d) 時点, すなわち右側で剝離渦の 大きく出ている時点における風速べクトル図を示 

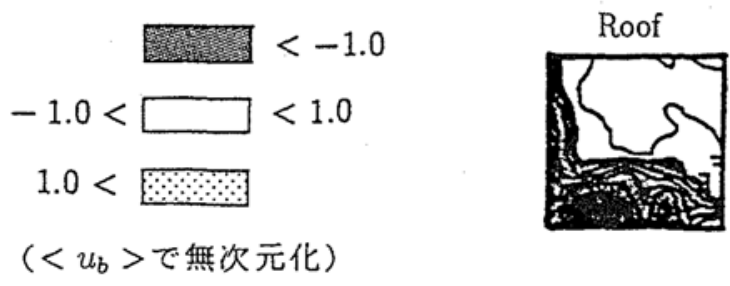

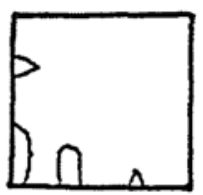

Leeward

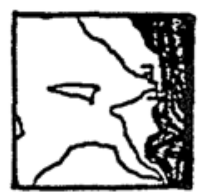

Left Side

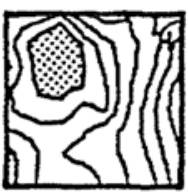

Windward

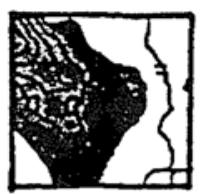

Right Side

（1）図4(1)の (a) 時点（壁面の左右は風上から見た方向）

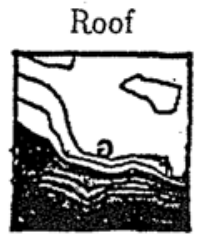

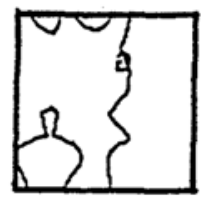

Leeward

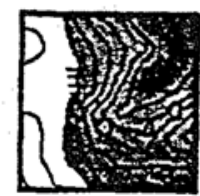

Left Side

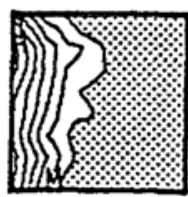

Windward

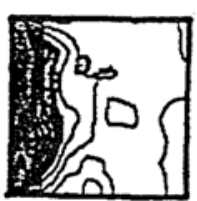

Right Side

（2）図 4(1)の (b) 時点

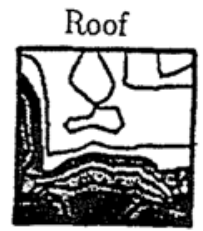

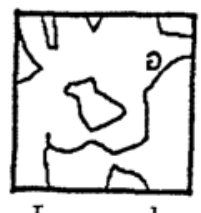

Leeward

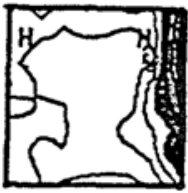

Left Side

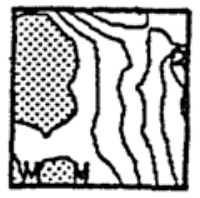

Windward

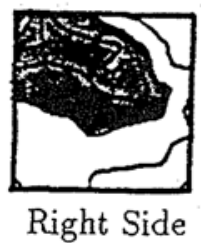

（3）図 4(1) の (c) 時点

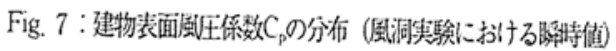




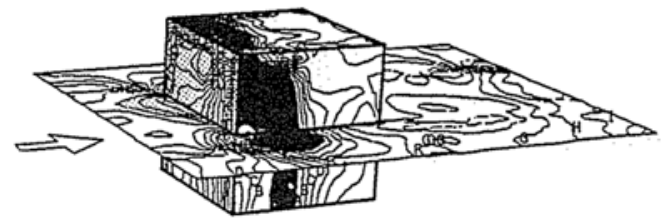

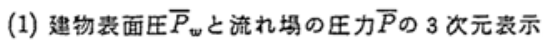

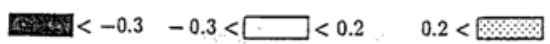

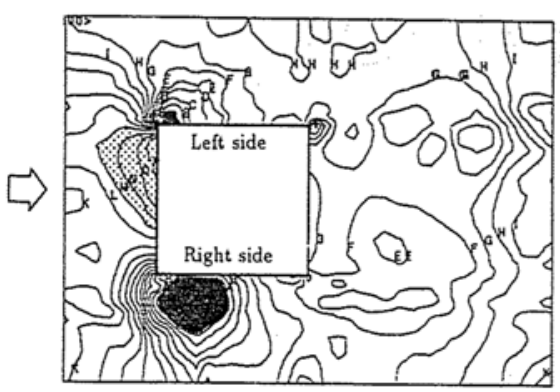

(2) 流れ堨の开力 $\bar{P}$ の水平面 $(Z=H b / 2)$

Fig. 8 : 建物表面圧 $\overline{\mathrm{P}}_{\mathrm{w}}$ と流れ場の圧力 $\overline{\mathrm{P}}$ の分布 （数值解析による瞬時値，Fig. 4(2)の (d) 時点)

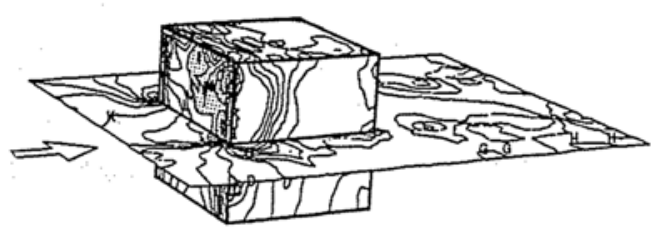

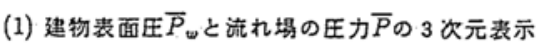

$<-0.3-0.3<\square<0.2 \quad 0.2<\square$

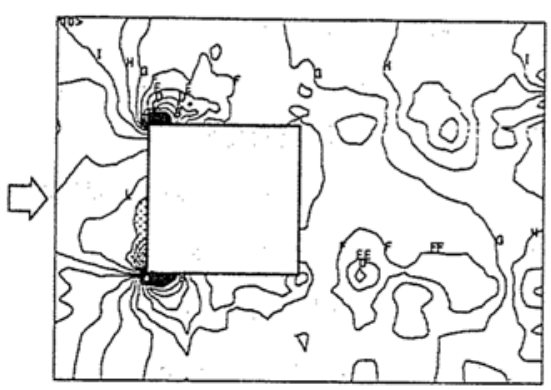

（2）流れ場の正力 $\bar{P}$ の水平面 $(Z=H b / 2)$

Fig. 9 : 建物表面圧 $\overline{\mathrm{P}}_{\mathrm{w}}$ と流れ場の圧力 $\overline{\mathrm{P}}$ の分布 （数値解析による瞬時値, Fig. 4(2)の (e) 時点)

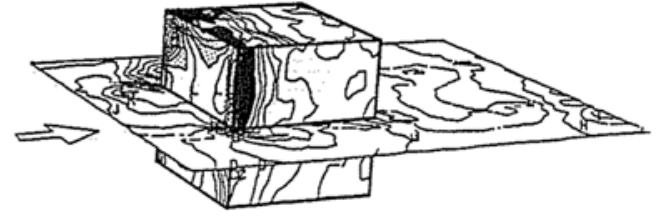

(1) 建物丧面代 $\bar{P}_{w}$ と流れ埸の压力 $\bar{P}$ の 3 次元表示
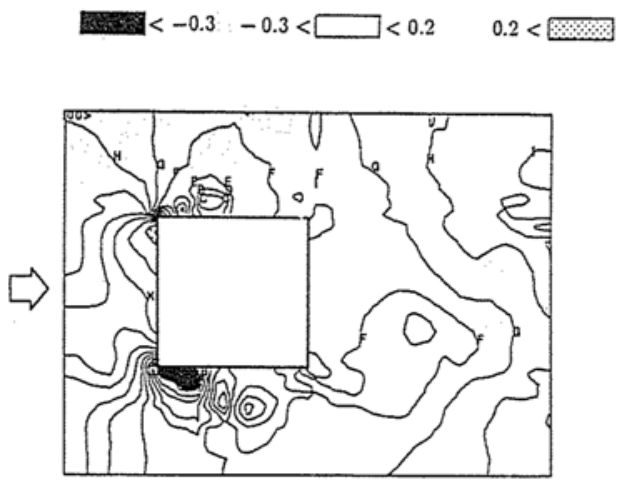

(2) 流れ埸の丘力 $\bar{P}$ の水平面 $(Z=H b / 2)$

Fig. 10: 建物表面圧 $\overline{\mathrm{P}}_{\mathrm{w}}$ と流れ場の圧力 $\overline{\mathrm{P}}$ の分布 (数値解析による瞬時値, Fig. 4(2)の (f) 時点)

す。数值解析でもFig. 7の風洞実験同様, 他の時点 と比較して差圧のピーク値が大きくなっている時 点に着目して抽出した。(e)時点の前後では差圧の のピーク値はそれほど大きくないが変動にやや周 期性が認められる (周期は無次元時間で 5 程度)。 また (f) 時点の前後の変動は (e) 時点前後の変動と 類似しているがその周期は多少長くなっている。

Fig.8に示す数値解析の建物表面の圧力分布を見 ると風洞実験のFig. 7(1)に見られるような大きな負 圧領域が建物右側の側壁面に現れている。これは Fig. 11に示す数値解析の風速ベクトル図に見られ る建物右側角部近傍の非常に大きな剩離渦に対応 しているものと思われる。Fig. 9の時点では建物 角部の剝離渦は小さく両側面の剝離渦の規模の差 もあまり大きくないため差圧は小さくなっている。 Fig. 10の時点も劋離渦の規模はさほど大きくない が他の時点と異なるのは解部から下流にかけて小 規模の制離渦が連続して生じていることである。 


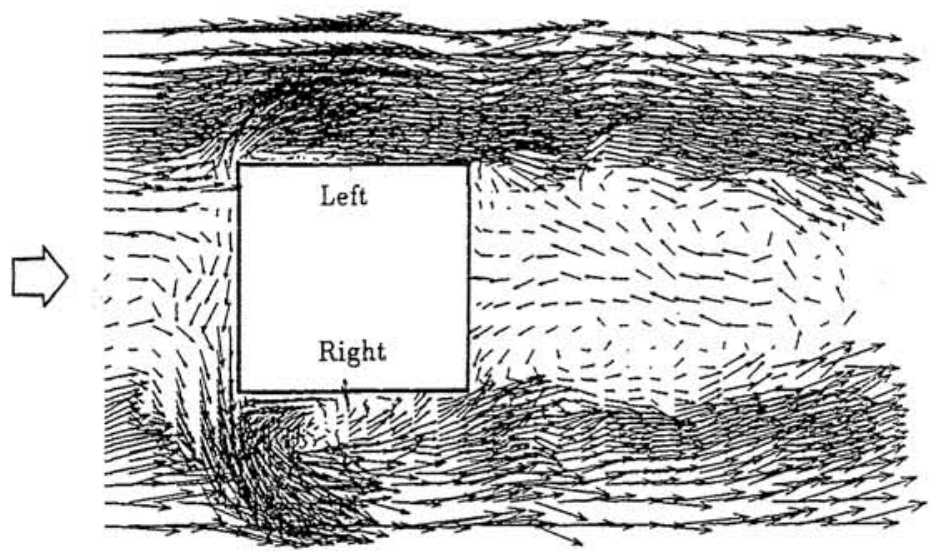

Fig. 11：風速ベクトル図

( $\mathrm{Z}=\mathrm{Hb} / 2$ の水平断面における瞬時値, Fig. 4の (d) 時点, Fig. 8に対応)

このような手法で数值解析と風洞実験の表面圧 カのパターンを比較すれば，例えば大きな差圧の ピーク値を示す時点に着目すると，(1)片側の側 壁面に大きな負圧の占める領域が広くなること， (2) 風上面の正圧の大きな値を占める領域が大き な負圧の生じる壁面とは反対側の側壁面の㑇部に 偏って発生する点など, 両者の圧力分布の特徴が よく一致していることがわかる。

\section{7. 数值解析による剥離渦の非定常变動}

Fig. 12にFig. 4(2)に示した (d) 時点の前後6時点 の連続的な剝離渦の挙動を表示する。Fig. 12(4)が (d) 時点に対応している。風上からみて左側面の 負の圧力領域 (Fig. 12(1)) が時刻の経過と共に弱 まり, 反対側の負の圧力領域が逆に強まって行く (Fig. 12(4)) 状況がよく観察される。渦の発生か ら消滅までは無次元時間 $\mathrm{t}$ *で約10 20程度である。 側面差圧の最も大きくなる(d)の時点で右側の負圧 の領域が最も大きくなり, その後徐々に減衰して 行き最後は非常に小さな渦に分解される。このよ うな圧力場の空間分布の解析は, 数值解析により はじめて可能となったものである。

\section{8. 結 論}

数値解析と多点圧力測定システムを併用するこ とにより街区周辺の圧力を中心とした乱流場の変 動性状について以下に示す多くの知見を得た。

1. 多点同時圧力測定システムにより街区モデル の建物表面の非定常変動圧パターンを実験に より初めて測定した。また数值解析により建 物表面のみでなく空間の圧力場の変動性状を 明らかにした。

2. 建物前後差圧, 建物側面差圧の変動波形は風 洞実験と数值解析との間で定性的に似た傾向 を示す。また壁面風圧分布の変動の性状も， 実験と数值解析でよく似たパターンを示す。

3. 実験における側面差圧のスペクトルは前後差 圧のスペクトルに比較して狭帯域であり,や や高周波側に偏っている。これらの特徵は数 值解析でよく再現されている。

4. 風洞実験により建物表面圧力，数值解析によ り建物表面圧力及び流れ場全体の圧力場を解 析し, 建物側面差圧が大きくなる時点では建 物角部に大きなスケールの剝離渦が存在する ことが確認された。 


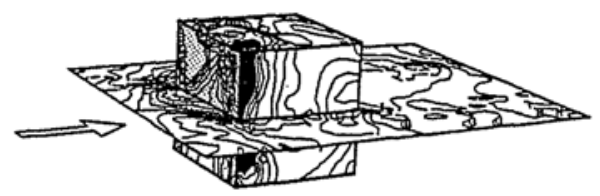

$t^{*}=14.2$

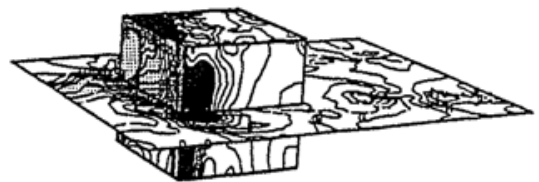

$t^{*}=15.2$

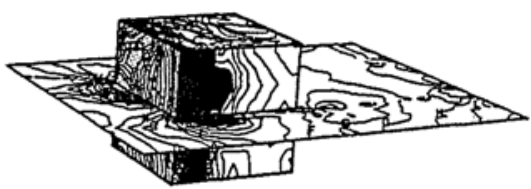

$t^{*}=16.2$

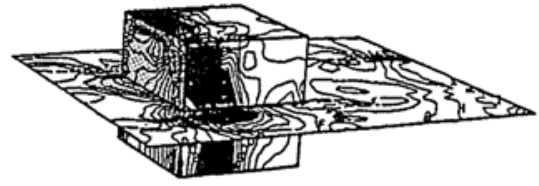

$t^{*}=17.3$

(Fig. 4の (d) 時点に対纫)

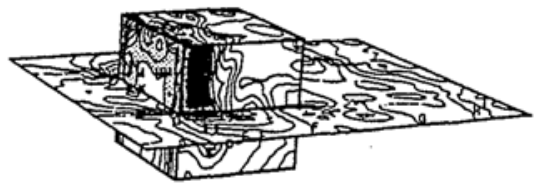

$t^{*}=18.8$

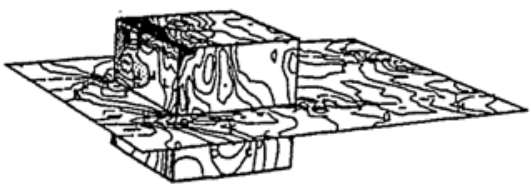

$t^{*}=19.3$

20.5. $\square<0.2 \quad 0.2<$ ख

（1）建物表面圧 $\bar{P}_{w}$ と流れ場の圧力 $\bar{P} の 3$ 次元表示
(1)

(2)

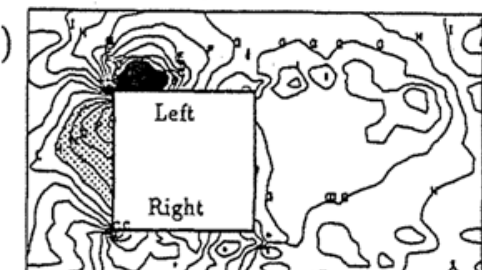

2)
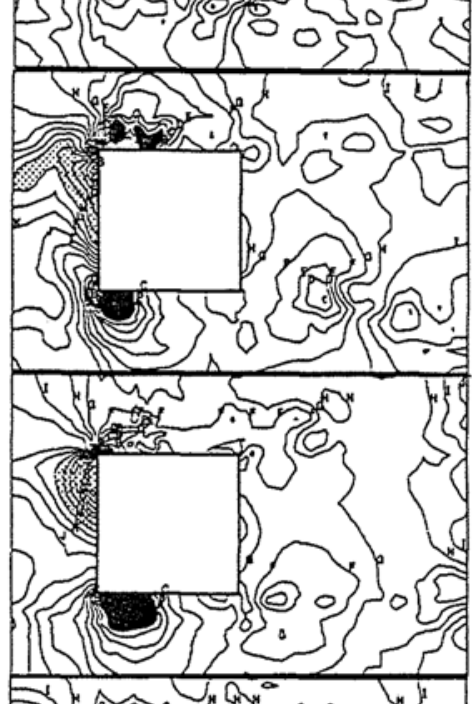

(4)

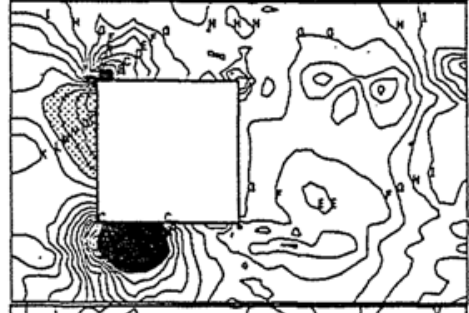

(5)

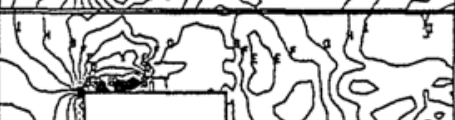

(6)

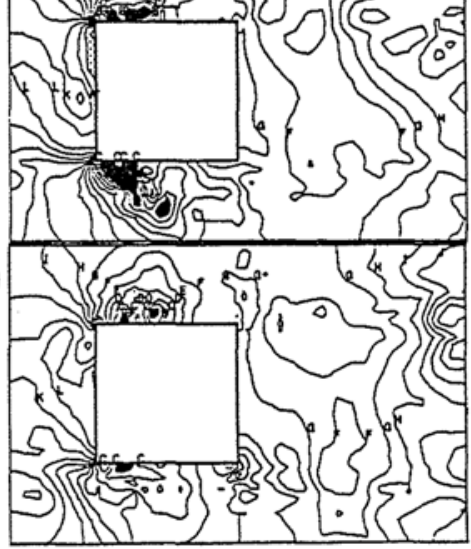

(2) 流れ場の压力 $\bar{P}$ の水平面分布 ( $Z=H b / 2$ における高さ)

Fig. 12：制離域における渦の非定常変動（数値解析） 
5. 建物側面差圧が大きなピーク值を示す前後の 建物角部の剥離渦の発生から消滅の過程を, 数値解析に基づく流れ場の圧力の分析により 明らかにした。発生から消滅までは無次元時 間 $\mathrm{t}$ *で10 20程度の長さであった。

6. 建物側面差圧の值がそれほど大きくない状態 において, 差圧が小さなピーク値を示す時の 流れ場の圧力場を観察すると, 小規模の剝離 渦が建物角部から下部にかけて連続して存在 している状況が観察された。

なお, 本報で紹介した変動圧パターンは膨大な データーのごく一部であり, 今後これらの計算值, 実験値の連続画像を観察することにより，さらに 多面的な考察を行いたいと考えている。

\section{参考文献}

（1）村上, 日比, 持田，LESによる街区周辺の流 れ場の数值解析と風洞実験 (その 7 ) 建物 表面, 周辺の圧力分布の検討 日本建築学会 大会学術講演稿概集, 1989.10

（2）村上, 日比, 持田, LESによる街区周辺の流 れ場の解析と風洞実験建物周辺および表面 の圧力場の検討 日本風工学会誌, 第41号, 1989. 10

（3）村上, 持田, 日比, LESによる街区周辺の流 れ場の数値解析と風洞実験 (その 3 ) 隣棟 間隔の変化が流れ場に及ぼす影響 日本建築 学会大会学術講演稿概集, 1988.10

（4）村上, 持田, 日比, Large Eddy Simulation による建物周辺気流の 3 次元数值解析（そ の1）日本建築学会計画系論文報告集, Vol. 2, pp1-11, 1986

(5) Murakami, S. ,Mochida, A. ,Hibi, K. ,Numerical Prediction of Velocity and Pressure Field around Building Models,7th Int. Conference on Wind Eng., 1987.7

(6) Murakami, S. ,Mochida, A. ,Hibi, K. ,Three-Di- mensional Numerical Simulation of Air Flow around a Cubic Model by Means of Large Eddy Simulation, J. Wind Eng. Ind. Aerodyn., Vol. 25, 1987, pp291-305

（7）藤井, 日比, 上田, 非定常風圧力の多点同 時測定方法と建物模型への応用について, 風工学シンポジウム, 1986.12

（8）藤井, 日比, 上田, 多点圧力同時測定シス テムを用いた角柱表面の変動圧の可視化, 流れの可視化;Vol. 7,No. 26,1987.7

（9）藤井, 日比, 上田, 多点圧力同時測定シス テムを用いた角柱表面の変動圧の可視化 (その 2) 角柱のアスペクト比と変動圧パ ターンの関係について, 流れの可視化, Vol. 8, No. 30, 1988

(10) Fuji, K. ,Hibi, K. ,Ueda. ,H, Shimada, K. , Visualization of Fluctuating Surface Pressure Distribution on Bluff Body using Electronically Scanning Pressure Sensors, 5th Int. Symposium on Flow Visualization, 1989. 8

記号

$\langle\mathrm{f}\rangle$ 変数 $\mathrm{f}$ 時間平均 ( (又はアジサンブル平均)

$\mathrm{f}$ : 変数fの格子平均 (ここではfilteringによる 空間平均)

$\mathrm{f}^{\prime \prime}, \mathrm{f}^{\prime}$ : 平均からのずれ

$f^{\prime \prime}=f-\bar{f}, f^{\prime}=f-\langle\bar{f}\rangle$, (実験ではf' $=f-<f \gg$ )

$u_{i}$ : 風速の 3 成分, $i($ 又は $x, u)$ :主流方向, $\mathrm{j}($ 又はy, v) : 横方向, $\mathrm{k}$ (又は $\mathrm{z}, \mathrm{w})$ : 鉛直方向 $\mathrm{P}$ : : 圧力 ( $\mathrm{Po}$ 基準), $\mathrm{Pw}$ : 壁面圧力 $\mathrm{Po}$ : 基準圧力 (上空静圧, LESではZ $=6 \mathrm{Hb}$, 実験 ではZ $=17 \mathrm{Hb}$.における静圧。但し,上空では高 さの差による静圧変化はほとんどない) $\mathrm{k}$ : 乱流エネルギー, $\mathrm{k}=\frac{1}{2}\left\langle\mathrm{u}_{\mathrm{i}} \mathrm{u}_{\mathrm{i}}{ }^{\prime}+\overline{\mathrm{u}_{\mathrm{i}}{ }^{\prime \prime} \mathrm{u}_{\mathrm{i}}{ }^{\prime}}\right\rangle$ 
$\mathrm{k}^{*}$ : subgrid scaleの乱流エネルギー

$$
\mathrm{k}^{*}=\frac{1}{2} \overline{\mathrm{u}_{\mathrm{i}}{ }^{\prime \prime} \mathrm{u}^{\prime \prime}}
$$

$v$ : 分子粘性

$\nu_{\text {sGS }}$ : 格子スケール (subgrid scale) の渦粘性

$\Delta:$ 格子スケール $(\Delta \mathrm{x} \cdot \Delta \mathrm{y} \cdot \Delta \mathrm{z})$,

$$
\Delta \text { iはメッシュ幅 }
$$

$\mathrm{C}_{\mathrm{s}}$ : Smagorinsky定数

$\mathrm{H}_{\mathrm{b}}$ : 建物高さ

$\mathrm{u}_{\mathrm{b}}$ : 建物上流, 建物高さ $\left(1 \mathrm{H}_{\mathrm{b}}\right)$ における風速

$\mathrm{C}_{\mathrm{P}}$ : 風圧係数 (壁面各点の瞬時値),

$$
\mathrm{C}_{\mathrm{P}}=\left(\mathrm{P}-\mathrm{P}_{0}\right) /\left(\rho<\mathrm{u}_{b}>^{2} / 2\right)
$$

$\Delta P_{D}:$ 建物前後差圧（瞬時の面内平均値，

風上壁面 - 風下壁面,

基準動圧 $\frac{1}{2} \rho<u_{b}>2$ で無次元化)

$\Delta P_{L}$ : 建物側面差圧 (瞬時の面内平均值,

ここでは左側壁面一右側壁面,

$\frac{1}{2} \rho<u_{b}>2$ で無次元化)

$t^{*}$ : 無次元時間 $t^{*}=t \cdot<u_{b}>/ H_{b}$

諸量の無次元化は建物高さ $\mathrm{H}_{b}$ と棟高風速 $<u_{b}>$ で行っている。 